\title{
Salminus franciscanus, a new species from the rio São Francisco basin, Brazil (Ostariophysi: Characiformes: Characidae)
}

\author{
Flávio C. T. Lima and Heraldo A. Britski
}

Salminus franciscanus, the large-sized dourado from the rio São Francisco basin, Brazil, is described. The new species was actually known ichthyologically since at least Valenciennes (in Cuvier \& Valenciennes, 1850) but it was never properly identified. Salminus franciscanus can be diagnosed from its congeners by the combination of the presence of an enlarged second tooth in the outer series of the dentary considerably larger than the remaining teeth, the absence of a dark post-orbital stripe, scale counts (68-82 lateral line scales, 11-14 horizontal series of scales between dorsal-fin origin and lateral line, and 68 horizontal series of scales between the lateral line and the pelvic-fin insertion), and a developed extension of the middle rays of the caudal fin. The historical taxonomy of the species is discussed.

Salminus franciscanus, o dourado de grande porte da bacia do rio São Francisco, Brasil, é descrito. Esta espécie, embora conhecida ictiologicamente desde meados do século XIX (Valenciennes, em Cuvier \& Valenciennes, 1850), nunca foi identificada de forma correta. Salminus franciscanus pode ser distinguida de suas congêneres pela combinação dos seguintes caracteres: presença de um dente da série externa do dentário consideravelmente maior que os demais dentes, ausência de uma faixa pósorbital escura, contagens intermediárias de escamas (68-82 escamas na linha lateral, 11-14 séries de escamas horizontais entre a origem da nadadeira dorsal e a linha lateral e 6-8 séries de escamas horizontais entre a linha lateral e a inserção da nadadeira pélvica) e um prolongamento mediano da nadadeira caudal bem desenvolvido. Um sumário sobre as discussões taxonômicas acerca da espécie presentes na literatura é apresentado.

Key words: Salminus brasiliensis, Salminus brevidens, Salminus cuvieri, Dourado, Misapplied name.

\section{Introduction}

Salminus is a genus of mid- to large sized characid fishes (ranging from 15 to at least $75 \mathrm{~cm} \mathrm{SL}$ ), occurring in the Amazon, Orinoco, La Plata and São Francisco river basins in cisandean South America and in the río Magdalena and a few other river drainages in transandean portions of the continent. Species of the genus are vernacularly called as "dourado" or "tabarana" in Brazil, and as "dorado", "dorada" or "pirayú" in Spanish-speaking South American countries. Salminus are well-known as one of the main targets of both commercial and amateur fisheries in the La Plata and São Francisco river basins. Salminus species are predatory, mainly piscivorous fishes, which inhabit large rivers and undertake spawning migrations during the rainy season (cf., e.g., Moraes Filho \& Schubart, 1955; Godoy, 1975; Sverlij \& Espinach Ros, 1986; Esteves \& Pinto Lôbo, 2001; Rodríguez-Olarte \& Taphorn, 2006). The phylogenetic relationships of Salminus are still unclear. The genus is usually considered, on morphological grounds, a basal characid (e.g., Géry, 1977; Malabarba \& Weitzman, 2003). Phylogenetic analysis using molecular data has suggested Salminus to be the sistertaxon of Brycon (Ortí \& Meyer, 1997; Calcagnotto et al., 2005), another purported basal characid, a view contradicted by mor- phology (Roberts, 1969; Lima, 2006).

In spite of the great popularity and economical importance of Salminus, our knowledge of the taxonomy of the genus is still unsatisfactory. This is a common situation among many South American freshwater fishes groups, even among large-sized, economically important fishes (Böhlke et al., 1978; Vari \& Malabarba, 1998). Eigenmann's (1916) brief revision of the genus, actually solely a key for the species based on the examination of less than 20 specimens, was, for a long time, the main taxonomic work for the genus. Eigenmann (1916) recognized four valid Salminus species: S. maxillosus, from the La Plata basin, S. brevidens, endemic to the rio São Francisco basin, S. hilarii, occurring in the Paraná, São Francisco, Amazon, and Orinoco river basins, and S. affinis, of the río Magdalena in Colombia. Virtually no changes to this taxonomy of the genus were proposed until Géry \& Lauzanne (1990). That study, which was focused on the type specimens of almost all nominal species of the genus, in the MNHN and NMW collections, challenged the nomenclature for Salminus adopted by Eigenmann (1916) and followed by subsequent authors. Their main finding was that Hydrocynus brasiliensis Cuvier, the oldest name available for a species in the genus and usually applied to for the large-sized Salminus species from the rio São Francisco basin (e.g., Britski et al., 1984),

Museu de Zoologia da Universidade de São Paulo, Caixa Postal 42494, 04299-970 São Paulo, SP, Brazil. (FCTL) fctlima@usp.br; (HAB): heraldo@usp.br 
was actually based on a specimen probably collected at the upper rio Paraguay basin, as evidenced by the fewer scales in that species than occur in the large-sized Salminus species occurring at the rio São Francisco basin. They concluded that Hydrocynus brasiliensis is rather applicable to the large-sized Salminus occurring at the La Plata basin, with Hydrocyon brevidens, S. cuvieri, S. maxillosus and S. orbygnianus all synonyms of $H$. brasiliensis. The first two of these are objective synonyms, since they were both based on the holotype of Hydrocynus brasiliensis. As a consequence of this shift in the usage of the name Hydrocynus brasiliensis, the large-sized Salminus from the rio São Francisco, identified as S. cuvieri by Steindachner (1880), S. brevidens by Eigenmann (1916), and $S$. brasiliensis by Géry (1977) and Britski et al. (1984), was left nameless. Due to the lack of adequate material, Géry \& Lauzanne (1990) refrained from formally naming the species.

During a revisionary study of Salminus conducted by the senior author (Lima, 2006), we confirmed the conclusions reached by Géry \& Lauzanne (1990) on the identity of Hydrocynus brasiliensis and on the absence of an available name for the Salminus species from the rio São Francisco ba$\sin$. Considering that this is a large-sized fish, important as a fishery resource and recognized since a long time as distinct by ichthyologists, we consider it unwise to postpone further its description. We, therefore, take this opportunity to finally baptize this long-known, yet still unnamed dourado species.

\section{Material and Methods}

Counts and measurements were taken according to Fink \& Weitzman (1974) and Menezes \& Weitzman (1990), with the addition of head height, measured at the vertical that passes through the basis of the supraoccipital process. Most measurements were taken with a caliper, to the nearest $0.1 \mathrm{~mm}$. Standard length and a few other measurements of large-sized specimens ( $>400 \mathrm{~mm} \mathrm{SL}$ ) were taken with a divider and a rule, to the nearest $1 \mathrm{~mm}$. Lateral line scale counts includes all pored scales, including those posterior to the hypural joint.

The frequency of each count is provided in parentheses after the respective count. An asterisk indicates counts of the holotype. Vertebrae and supraneurals counts were obtained from two cleared and stained (cs) specimens (MZUSP 79859) and five radiographed specimens (MZUSP 79859, MZUSP 19524). Vertebrae counts were also obtained from a single skeletonized (skel.) specimen (MZUSP 89512). Vertebrae of the Weberian apparatus were counted as four elements and the fused PU1 + U1 of the caudal region as a single element. Specimens were cleared and stained following Taylor \& Van Dyke (1985). The skeletonized specimen was prepared following the methods outlined by Bemis et al. (2004), except that no previous neurocranium dissection was performed. Institutional abbreviations are: $\mathrm{BMNH}$ (The Natural History Museum, London), MCP (Museu de Ciências e Tecnologia, Pontifícia Universidade Católica do Rio Grande do Sul, Porto Alegre), MNHN (Muséum National d'Histoire Naturelle, Paris), MHNUC-IC (Museo de Historia Natural, Universidad del Cauca, Popayan, Colombia),
MNRJ (Museu Nacional, Rio de Janeiro), MZUSP (Museu de Zoologia da Universidade de São Paulo, São Paulo), NMW (Naturhistorisches Museum, Vienna), and UFPB (Coleção ictiológica da Universidade Federal da Paraíba, João Pessoa).

\section{Salminus franciscanus, new species}

Figs. 1-3

Salminus cuvieri (not Valenciennes): Valenciennes, 1850: 62 (in part; "Rio San Francisco"); Lütken, 1875a: 142 (popular name; rio São Francisco and rio Cipó); Lütken, 1875b: 227232 (rio das Velhas; rio São Francisco); Steindachner, 1880: 82-83 (rio das Velhas; rio San Francisco); Lütken, 2001: 116121 (rio São Francisco and rio das Velhas, Minas Gerais).

Salminus brevidens (not Cuvier): Müller \& Troschel, 1844: 91 ("Brasilia"; doubtful identification); Müller \& Troschel, 1845: 16, pl. 8, fig. 3 (teeth) (idem); Günther, 1864: 350 (“Cipó River"); Eigenmann, 1916: 91 (Joazeiro; Penedo; Cidade do Barra (= Barra)); Moraes \& Schubart, 1955: 11 (rio São Francisco, distribution).

Salminus brasiliensis (not Cuvier): Britski et al., 1984: 52, fig. 49 (Minas Gerais, Três Marias); Petrere Jr, 1989: 11 (rio São Francisco, Três Marias; fisheries); Sato \& Godinho, 1999: 406, 410 (rio São Francisco, Minas Gerais; ecology, size, migrations, eggs and larvae); Alves \& Pompeu, 2001: 183 (Minas Gerais, rio das Velhas); Nakatani et al., 2001: 105109, figs. 23-24 (egg and larvae development); Santos \& Godinho, 2002: 163-171 (early ontogeny, larvae morphology and behaviour); Sato \& Godinho, 2003: 204, 208, 210, 215-216 (rio São Francisco, Minas Gerais; migrations, fisheries).

Salminus sp. : Géry \& Lauzanne, 1990: 120-123, fig. 5 (rio São Francisco; taxonomic discussion, diagnosis); Pompeu \& Godinho, 2006: 430 (Minas Gerais, rio São Francisco, Itacarambi, occurrence in floodplain lagoons).

Holotype. MZUSP 89625 (324.0 mm SL), Brazil, Minas Gerais, Pedro Leopoldo, stream tributary to rio das Velhas, at Igreja

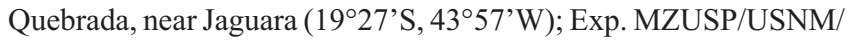
UFSCAR, 19 Jul 1994.

Paratypes: Brazil, rio São Francisco basin, Minas Gerais: MZUSP 19926 (2, 192.0-247.0 mm SL), rio São Francisco, Três Marias; CODEVASF, 1978. MZUSP 19524 (2, 125.0-134.3 mm SL), rio São Francisco, Três Marias; M. Tozzi da Silva, 1964. MZUSP 51517 (3, 169.0-200.4 mm SL), Fortuna de Minas, rio Paraopeba, lagoa Massaracá, $19^{\circ} 34^{\prime}$ S, 44³4’W; C.B.M. Alves and team, 19 Mar 1996. MZUSP 73808 (1, $230.0 \mathrm{~mm} \mathrm{SL})$, Lassance, rio das Velhas, at the crossing of the ferry-boat, $17^{\circ} 54^{\prime} 45^{\prime \prime} \mathrm{S}, 44^{\circ} 34^{\prime} 20^{\prime \prime} \mathrm{W}$; C.B.M. Alves \& P.S. Pompeu, 28 Jun 2000. MZUSP 73833 (1, $310.0 \mathrm{~mm} \mathrm{SL}$ ), Santo Hipólito/Corinto, rio das Velhas, Nossa Senhora da Glória, village of Caquende, 18²4'56' 'S, 44¹1'20' 'W; C. B. M. Alves \& P. S. Pompeu, 18 Jun 1999. MZUSP 47244 (6, 189.4-324.0 $\mathrm{mm}$ SL), Pedro Leopoldo, stream tributary to rio das Velhas, at Igreja Quebrada, near Jaguara; Exp. MZUSP/USNM/UFSCAR, 19 Jul 1994. MZUSP 39727 (16, 228.0-302.0 mm SL), rio São Francisco and tributaries, UHE Formoso region (downstream from Pirapora); Y. Sato, Nov 1987 to Aug 1988. MZUSP 38999 (1, $451.0 \mathrm{~mm} \mathrm{SL);}$ MZUSP 39000 (1, $773.0 \mathrm{~mm} \mathrm{SL})$, same data as previous. MZUSP 39691 (9, 172.5-253.0 mm SL), rio São Francisco, Pontal do Abaeté; 


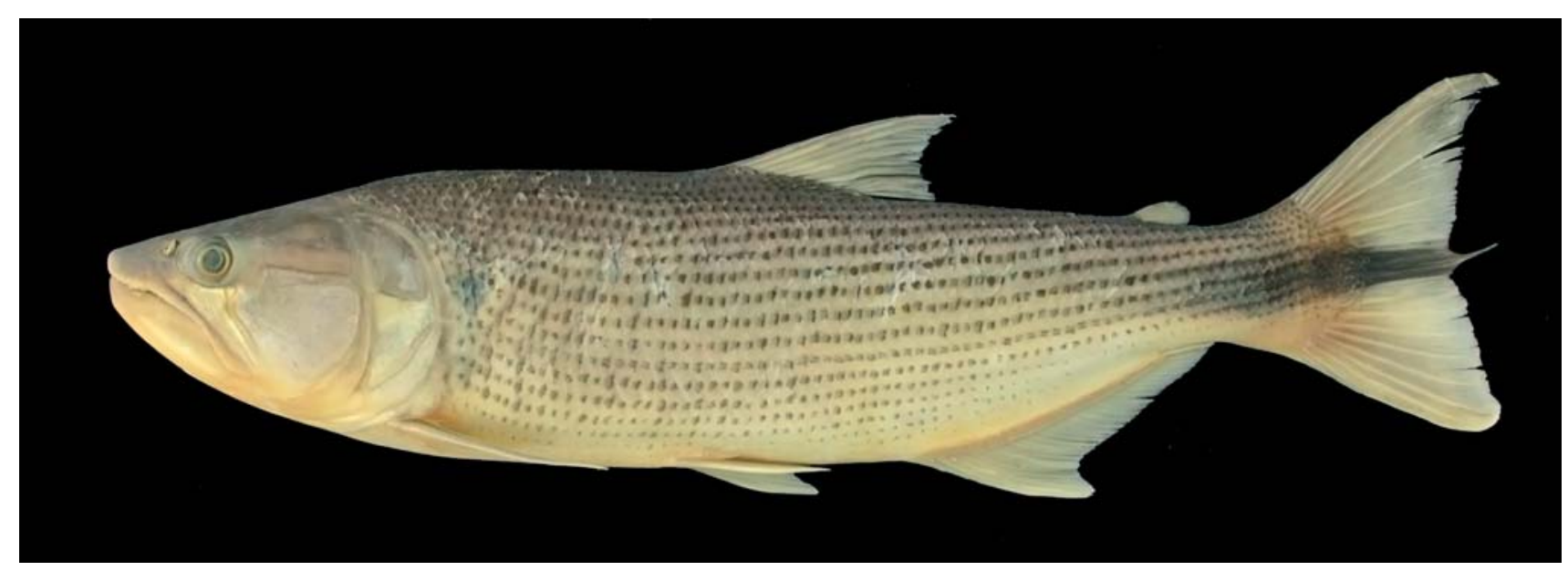

Fig. 1. Salminus franciscanus, holotype, MZUSP 89625, 324.0 mm SL; Brazil, Minas Gerais, stream tributary to rio das Velhas.

Y. Sato (UHE Formoso project), 22 Jul 1988. MZUSP 39683 (1, $200.7 \mathrm{~mm}$ SL), córrego Espraiado, rio Abaeté; Y. Sato (UHE Formoso project), 21 Jul 1988. MZUSP 42071 (3, 185.8-361.0 mm SL), lagoa Mocambinho, rio São Francisco right margin, Manga; J. C. Oliveira \& O. T. Oyakawa, 22 Jul 1990. MNRJ 25995 (3, 158.2-353.0 mm SL), Manga, stream and lagoon at Mocambinho, rio São Francisco right margin; J. C. Oliveira \& O. T. Oyakawa, 17-22 Sep 1990. MNRJ 17376 (1, 217.6 mm SL), Manga, lagoa de Mocambinho (rio São Francisco right magin), Mocambinho; J. C. Oliveira \& M. S. Menezes, 8 Mar 1990. MNRJ 16137 (1, 167.9 mm SL), Manga, rio São Francisco, ilha do Caju (right margin), downstream from Mocambinho; D. F. Moraes Jr. \& J. C. Oliveira, 21 Aug 1990. MNRJ 17373 (1, 143.1 mm SL), Manga, riacho Mocambinho (rio São Francisco right margin), Mocambinho; J. C. Oliveira, M. S. Menezes \& E. Carelis, 6 Apr 1990. MNRJ 17387 (2, 167.2-219.1 mm SL), Manga, artificial channel (rio São Francisco right margin), Mocambinho; J. C. Oliveira \& M. S. Menezes, 11 Mar 1990. MNRJ 17408 (3, 246.7-265.4 mm SL), Manga, rio São Francisco at Mocambinho (artificial channel, right margin); J. C. Oliveira \& M. S. Menezes, 3 Apr 1990. MNRJ 17391 (1, 288.2 mm SL), Manga, artificial channel (rio São Francisco, right margin), Mocambinho; J. C. Oliveira \& M. S. Menezes, 5 Apr 1990. MNRJ 16364 (1, 100.8 mm SL), Manga, artificial channel, rio São Francisco (right margin), Mocambinho; J. C. Oliveira, 11 Dec 1989. MZUSP 54754 (1, $205.0 \mathrm{~mm}$ SL), Januária, rio Pandeiros, 48 km from Januária, 15³0'48' S, 4445'12'”W; S. A. Schafer et al., 14 Jul 1993. BMNH 1924.6.2.2 (1, 323.0 mm SL), Jaguara, rio das Velhas (about 32 miles north of Belo Horizonte); Chalmers. BMNH 1924.6.16.6 (1, 755.0 mm SL), same data as previous. Bahia: MZUSP 28797 (17, 165.9-237.0 mm SL), rio das Fêmeas, near Barreiras; M. A. Cestarolli \& J. Camargo, 2-6 May 1985. MZUSP 79859 (5, 2 cs, 98.9-156.0 mm SL), Barra, rio Grande, tributary of rio São Francisco, Cabeça de Touro beach, $11^{\circ} 6^{\prime} 8^{\prime \prime}$ S, 439'26' W; O. T. Oyakawa, A. Akama \& J. C. Nolasco, 10 Apr 2001. UFPB 2571 (1, 226.0 mm SL), Santa Maria da Vitória, rio Corrente; G. Gomes Filho, Oct 1992. MZUSP 20443 (1, 297.0 mm SL), rio São Francisco, downstream Sobradinho; R. dos Santos, 13 Oct 1976.

Not types: Brazil, rio São Francisco basin, Minas Gerais: MCP 14123 (4, 261.1-273.1 mm SL), Três Marias, rio São Francisco between Três Marias and Pirapora. MZUSP 1534 (3, 118.3-262.0 mm SL), rio São Francisco, Pirapora. MZUSP 1954 (2, 176.5-211.0 mm SL), Pirapora, stream tributary to rio São Francisco. MNRJ 21841 (4, 31.7-45.2 mm SL), Minas Gerais, Pirapora. MZUSP 89512 (1, skel., 225.0 mm SL), rio São Francisco. Bahia: NMW 81898 (1, $259.0 \mathrm{~mm}$ SL), "Rio das Velhas" (no specific locality). NMW 56860
(2, 140.3-144.0 mm SL), Santa Rita; Bras. Exped., January 1904. NMW 56862 (3, 121.0-134.0 mm SL), same data as previous. NMW 56858 (2, 145.0-146.4), Barra. Brazil, no specific locality: NMW 56867 (2, one measured, 209.0 mm SL), "Rio São Francisco". MNHN A.8556 (452.1 mm SL, stuffed), "Rio San Francisco".

Diagnosis. Salminus franciscanus can be diagnosed from all Salminus species, except $S$. brasiliensis, by the presence of a second dentary tooth in the outer tooth series that is considerably larger than the remaining teeth ( $v s$. second dentary teeth only slightly larger than remaining teeth in $S$. affinis and $S$. hilarii). Salminus franciscanus can be additionally diagnosed from $S$. affinis by the absence of the dark post-orbital stripe that is characteristic from the latter species. Salminus franciscanus can be diagnosed from $S$. brasiliensis in possessing much lower scale counts, i.e., lateral line (68-82, modally 77 scales, vs. vs. 79-102, modally 96), horizontal between dorsal-fin origin and lateral line (11-14, modally 12, vs. 14-18, modally 16) and horizontal between lateral line and pelvic-fin insertion (6-8, modally 6, vs. 6-9, modally 8). In spite of the great overlap, Salminus franciscanus has generally more lateral line (68-82, modally 77 scales, vs. 54-72, modally 65-66), horizontal between dorsal-fin origin and lateral line (11-14, modally 12, vs. $9-12$, modally 10), and horizontal between lateral line and pelvic-fin insertion (6-8, modally 6, vs. 4-7, modally 5), scales, when compared to the sympatric S. hilarii. In life, Salminus franciscanus can also be distinguished from $S$. hilarii by the presence of golden coloration mainly over the facial bones and pectoral girdle ( $v s$. facial bones and pectoral girdle silvery). See under "Remarks", below, for more details on the diagnosis of Salminus franciscanus regarding its congeners.

Description. Morphometric data presented in Table 1. Largesized species, larger specimen examined reaching $755 \mathrm{~mm}$ SL. Body relatively slender, moderately deeper in specimens larger than $360 \mathrm{~mm}$ SL. Greatest body depth at dorsal-fin origin. Dorsal profile of head and body slightly convex from margin of upper lip to vertical through anterior nostril, straight to slightly concave from latter point to supraoccipital spine, moderately convex from latter point to dorsal-fin origin, then 
straigth along dorsal-fin base and slightly convex to straight from posterior of dorsal-fin base to adipose-fin origin. Dorsal profile of caudal peduncle slightly concave. Ventral profile of head and body slightly convex from lower lip to pelvic-fin insertion, straight to slightly convex from latter point to analfin origin, and approximatelly straight along anal-fin base. Ventral profile of caudal peduncle slightly concave.

Head profile acute anteriorly. Mouth terminal. Maxilla extending posteriorly little beyond vertical through posterior margin of eye in specimens greater than $165 \mathrm{~mm}$ SL, not reaching latter point in smaller specimens. Adipose eyelid relatively well developed, covering anterior portion of eye. Premaxilla with two series of teeth. Teeth of outer series considerably larger that those of inner series other than for second tooth of inner series. Outer series with 4-8 teeth approximatelly equal in size; teeth with distinct, elongate basal portion (shaft), and apical portion (crown). Crown triangular, with angles possibly constituting poorly differentiated cusps. Inner tooth series with 7-15 teeth. Symphyseal tooth relatively large, second tooth slightly smaller, third and subsequent teeth considerably smaller. Teeth of inner series of form comparable to those from outer series, except for proportionally shorter shafts and being more massive overall. Middle portion of ventral margin of maxilla slightly concave. Maxilla with 23-37 teeth of form similar to those of outer series in premaxilla, but slightly smaller and decreasing very gradually in size posteriormost with less developed crowns. Last teeth conical. Dentary with 16 to 29 teeth on primary series; teeth similar in form to those of outer series in premaxilla outer series, and other than first through third teeth slightly smaller than those on premaxilla. Second teeth on primary series of dentary considerably larger than other teeth in that series in specimens of all sizes. Third through last teeth progressively decreasing in size with less developed crowns. Teeth of outer series of dentary, outer series on premaxilla, and teeth on maxilla with crowns slightly recurved lingually. Inner tooth series on dentary with 53-58 conical teeth arranged in continuous series from symphysis to terminus of inner rim of replacement teeth trench. Teeth in inner series oriented at right angle to teeth of primary series with apices directed lingually.
Scales cycloid. Lateral line complete, extending from supracleithrum to caudal-fin base. Lateral-line scales 68 (1), $70(1), 71(2), 72(6), 73(10), 74(7), 75(12), 76^{*}(13), 77$ (16), 78 (9), 79 (3), 80 (3), or 82 (1). Laterosensory tubes simple and straight or deflected downwards. Horizontal scales series between dorsal-fin origin and lateral line 11 (11), 12* (57), 13 (13), or 14 (1). Horizontal scale series between lateral line and pelvic-fin insertion $6^{*}(42), 7$ (34), or 8 (5). Circumpeduncular scales 21 (4), 22 (11), 23* (35), 24 (30), or 25 (3).

Dorsal-fin rays ii, 9 . Dorsal-fin origin approximatelly midway between snout and hypural joint. First dorsal-fin pterygiophore inserting behind neural spine of 14th (2), 15th (4), or 16th (1) vertebrae. Anal-fin rays iii (not including first, small unbranched ray discernible only on cs specimens), 23 (8), 24 (12), 25 (30), 26* (27), 27 (4), or 28 (1). First anal-fin pterygiophore inserting behind haemal spine of 26th (1), 27th (3), or 28th (4) vertebrae. Last unbranched ray and first and second anal-fin branched rays longer; third to ninth rays gradually shortening with remaining rays approximatelly equal in size. Pectoral fin rays i,12 (1), 13* (19), 14 (50), 15 (12), or 16 (1). Pelvic-fin rays i,7. Principal caudal fin rays 10/9. Anal fin with small hooks along last unbranched ray and anterior 1519 branched rays (MZUSP 39727, 235.0-283.0 mm SL, and MZUSP 20443, $297.0 \mathrm{~mm} \mathrm{SL}$ ). Hooks limited to posterior branch of rays. Pelvic fins with hooks on branched rays 1-6 of same specimens and limited to posterior branch. Scales sheath composed of two horizontal series covering basal portion of anal-fin rays. Caudal fin moderately forked to slightly emarginated. Laterosensory tube extending over interradial membrane between upper and lower caudal-fin lobes to caudal-fin terminus. Laterosensory tube on caudal fin with dorsally and ventrally oriented side branches across its length. Central caudal-fin extension well-developed, extending beyond primary margin of fin for distance equal to onethird to one-half beyond of length of median caudal-fin rays.

Branchiostegal rays 4. First gill arch with 14 (1), 15 (2), 16 (1), or 17 (1) lower gill rakers, 13 (3), 14 (1), or 15 (1) upper gill rakers and 1 at angle. Vertebrae 50 (2), 51 (2), or 52 (4). Supraneurals 11 (4) or 12 (3).

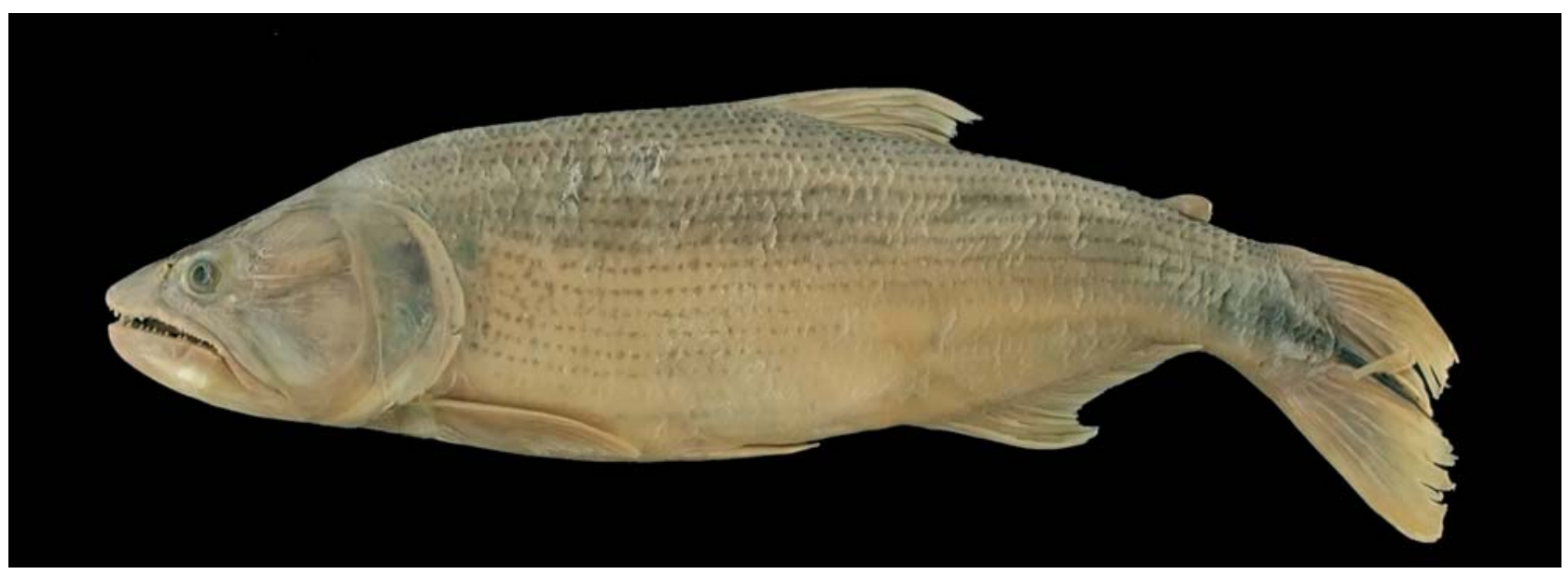

Fig. 2. Salminus franciscanus, paratype, MZUSP 38999, 451.0 mm SL; Brazil, Minas Gerais, rio São Francisco. 
Coloration in alcohol. Overall coloration from specimens still retaining guanine plumbeous-gray, with brownish hue dorsally. Top of head (including supraorbital, infraorbitals 4 and 5 , and dorsal portion of opercle), snout and anterior portion of maxilla brown. Remaining infraorbitals and ventral portion of opercle silvery. Lateral portions of body lightly colored, with silvery hue and dark-grey dorsally. Dark humeral spot present, but relatively inconspicuous. Spot horizontally ovoid, formed by pigmentation subjacent to scales, and situated above second and third lateral line scales. Dark, straight longitudinal stripes formed by dark chromatophores concentrated on mid to distal portions of each scale extending along trunk. Stripes more discernible dorsally. Caudal peduncle with broad median stripe, originating 3-5 scales from hypural joint and continuing posteriorly over 3-4 central principal caudalfin rays. Dorsal and anal fins with few chromatophores forming ill-defined dark stripes across interradials membranes. Pectoral, pelvic, and adipose fins clear, with few, scattered dark chromatophores. Specimens lacking guanine as result of long storage in formalin brown overall, without silvery hue on lateral portions of body, infraorbitals or opercle.

Life coloration. Description based on photographs of two freshly collected specimens from rio Paraopeba (not preserved; Fig. 3), one specimen from rio Urucuia (not preserved), and one specimen from rio São Francisco (MZUSP 89512). Dorsal portion of body and head dark gray; lateral portions of body lightly pigmented with silvery hue. Infraorbitals, opercular series, and pectoral girdle golden. Fins, including adipose fin, yellow-orangish but with reddish margin on caudal fin.

Sexual dimorphism. The presence of hooks on pelvic and anal fins (less often other fins) is considered to be a dimorphic sexual character, present in mature males of most Characidae (Malabarba \& Weitzman, 2003). Anal and pelvic fin hooks were found in several examined specimens of Salminus franciscanus (MZUSP 39727, 7, 235.0-283.0 mm SL, and MZUSP 20443, $297.0 \mathrm{~mm} \mathrm{SL}$ ). Two of these specimens (MZUSP 39727, 260 and $283 \mathrm{~mm} \mathrm{SL}$ ) were found to be males on dissection. Salminus franciscanus females are reported to grow larger than males of the species (Sato \& Godinho, 2003).

Common names: Brazil: dourado (e.g., Lütken, 1875b, 2001; Britski et al., 1984; Alves \& Pompeu, 2001).

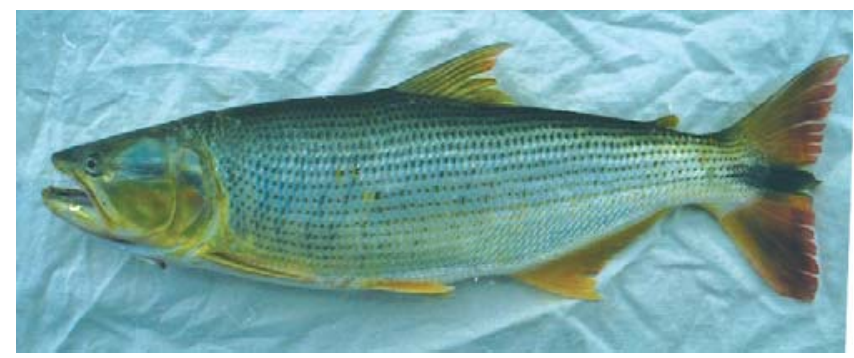

Fig. 3. Salminus franciscanus (not preserved), SL unrecorded, Brazil, Minas Gerais, rio Paraopeba, UTE Igarapé, 1957'S, $44^{\circ} 16^{\prime} \mathrm{W}$; coloration in life. Photo by Carlos B.M. Alves.
Distribution. Salminus franciscanus is endemic from the rio São Francisco basin, Brazil (Fig. 4).

Biology, ecology, and fisheries. There is little published information about the general biology and ecology of Salminus franciscanus, when compared to its much better known congener $S$. brasiliensis, an unfortunate fact since the species has been recognized as distinct (even if under misapplied names) since late XIX century. Salminus franciscanus is reported to reach one meter in total length and to weigh up to $30 \mathrm{~kg}$ (Sato \& Godinho, 1999, 2003; as S. brasiliensis; C.B.M. Alves, pers. comm.), being, consequently, one of the largest known Characiformes. It is a piscivore, which undertake reproductive migrations during the rainy season (Sato \& Godinho, 1999, 2003; as S. brasiliensis). Juveniles $(<600 \mathrm{~g})$ were collected in marginal lagoons of the rio São Francisco, which indicates that those are recruiting habitats for the species (Sato \& Godinho, 2003; as S. brasiliensis). Salminus franciscanus is one of the main targets of the commercial and amateur fisheries in the middle rio São Francisco basin (Petrere, 1989; Sato \& Godinho, 2003; as S. brasiliensis). The early larval development of the species was described by Santos \& Godinho (2002; as S. brasiliensis).

Etymology. Franciscanus, after rio São Francisco, the river basin from which the species is endemic.

\section{Discussion}

The first unequivocal mention in the literature of a specimen of Salminus franciscanus (incorrectly identified as $S$. cuvieri $[=$ S. brasiliensis $]$ ), was by Valenciennes (in Cuvier \& Valenciennes, 1850: 62), based on a specimen collected by the botanist Auguste de Saint-Hilaire in the rio São Fran-

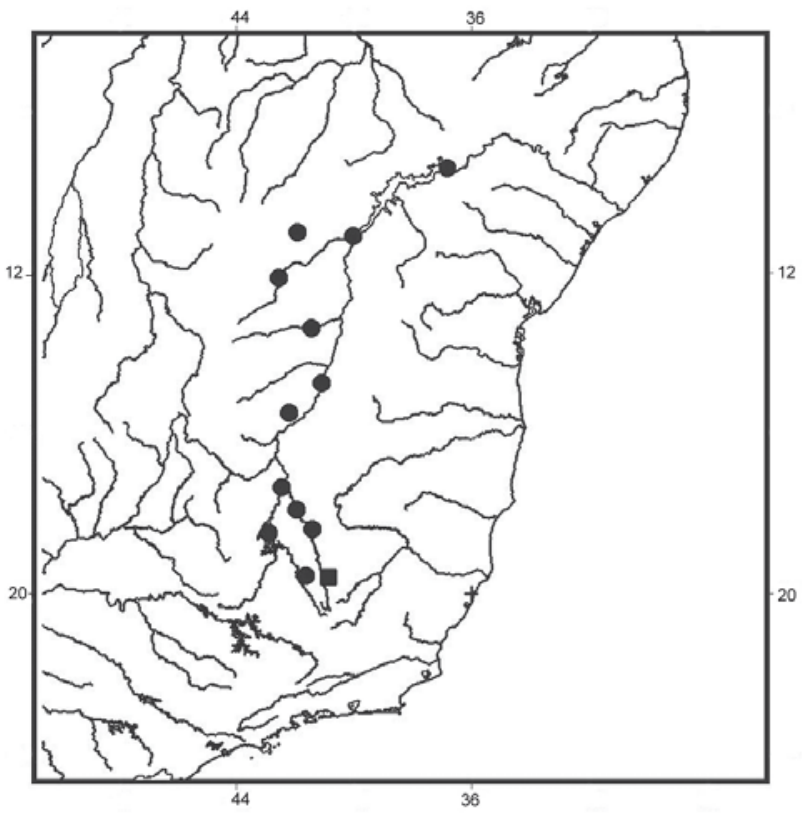

Fig. 4. Map of eastern and northeastern Brazil showing the distribution of Salminus franciscanus. A square indicates the type locality. 
Table 1. Morphometric data of Salminus franciscanus. A: MNHN A. 8556 (stuffed specimen, its data not included in the range or mean).

\begin{tabular}{|c|c|c|c|c|c|}
\hline & A & Holot. & $\mathrm{n}$ & Range & Mean \\
\hline Standard length (mm) & 452.1 & 324.0 & 83 & $125.0-755.0$ & - \\
\hline \multicolumn{6}{|c|}{ Percents of standard length } \\
\hline Depth at dorsal-fin origin & 21.1 & 23.8 & 77 & $23.8-34.0$ & 26.0 \\
\hline Snout to dorsal-fin origin & 52.5 & 49.0 & 83 & $48.0-54.2$ & 50.8 \\
\hline Dorsal-fin base length & 10.9 & 10.9 & 83 & $9.6-13.3$ & 11.8 \\
\hline $\begin{array}{l}\text { Posterior terminus of dorsal } \\
\text { fin to adipose fin }\end{array}$ & 21.6 & 22.3 & 83 & $20.5-25.7$ & 23.2 \\
\hline $\begin{array}{l}\text { Posterior terminus of dorsal } \\
\text { fin to hypural joint }\end{array}$ & 37.7 & 38.8 & 83 & $36.8-43.3$ & 39.9 \\
\hline Snout to pelvic-fin insertion & 47.2 & 47.4 & 77 & $43.5-51.0$ & 46.6 \\
\hline Snout to anal-fin origin & 69.4 & 64.5 & 83 & $61.7-73.4$ & 65.4 \\
\hline Anal-fin base length & 17.5 & 22.2 & 83 & $19.5-25.0$ & 22.4 \\
\hline Caudal peduncle length & 15.0 & 16.7 & 83 & $12.4-18.9$ & 16.5 \\
\hline Dorsal-fin height & - & 18.7 & 82 & $16.0-21.8$ & 19.3 \\
\hline Pectoral-fin length & - & 17.4 & 80 & $13.6-19.7$ & 17.4 \\
\hline Pelvic-fin length & - & 13.0 & 82 & $10.6-15.5$ & 13.3 \\
\hline Caudal peduncle depth & 8.6 & 8.9 & 83 & $8.2-9.9$ & 9.1 \\
\hline Head length & 28.4 & 27.0 & 83 & $24.2-29.3$ & 26.9 \\
\hline \multicolumn{6}{|c|}{ Percents of head length } \\
\hline Head height & 72.6 & 67.5 & 82 & $64.1-75.8$ & 69.1 \\
\hline $\begin{array}{l}\text { Snout to supraoccipital } \\
\text { process tip }\end{array}$ & 78.9 & 78.7 & 21 & $75.3-84.8$ & 80.4 \\
\hline Snout length & 26.4 & 27.6 & 83 & $23.4-30.1$ & 26.2 \\
\hline Upper jaw length & 57.2 & 57.0 & 83 & $49.3-63.8$ & 54.4 \\
\hline $\begin{array}{l}\text { Horizontal eye diameter } \\
\text { diameter }\end{array}$ & 14.3 & 16.1 & 82 & $13.1-21.7$ & 18.2 \\
\hline Post-orbital length & 61.8 & 60.0 & 83 & $53.5-63.1$ & 58.0 \\
\hline Least interorbital width & 26.4 & 28.4 & 83 & $25.4-34.7$ & 27.6 \\
\hline
\end{tabular}

cisco. The erroneous identification of that specimen to a species easily distinguishable by a considerably higher lateral line scale count (79-102 in Salminus brasiliensis, vs. 68-82 in $S$. franciscanus, respectively), might be ascribed, as noticed by Géry \& Lauzanne (1990: 120), to the low number of lateralline scales (80) reported by Valenciennes (in Cuvier \& Valenciennes, 1850: 61) for the holotype of $S$. cuvieri, a count almost identical to the 78 in the specimen of $S$. franciscanus (MNHN A.8556) available to that author. The holotype of Salminus cuvieri (which is also the holotype of Hydrocynus brasiliensis Cuvier and Hydrocyon brevidens Cuvier), actually possess 92 lateral line scales (although Cuvier, 1819, reported "plus de cent" scales for this same specimen), a value greater than that found in $S$. franciscanus (68-82).

The incorrect identification of a specimen of Salminus franciscanus by Valenciennes (in Cuvier \& Valenciennes, $1850)$ to $S$. cuvieri was the reason for the application of that name (Lütken, 1875a; Steindachner, 1880), and its senior synonyms $S$. brevidens (Günther, 1864; Eigenmann, 1916; Moraes \& Schubart, 1955) and S. brasiliensis (e.g., Britski et al., 1984) to the species. As noted by Géry \& Lauzanne (1990), none of those names is appropriatelly applied to the large-sized species of Salminus occurring in the rio São Francisco basin, which was, consequently, left unnamed up to now.

Given the pronounced similarity among the species of Salminus, the distinctness of $S$. franciscanus and its congeners was repeatedly discussed in the sparse literature dealing with the taxonomy of the genus. Lütken $(1875 b, 2001)$ was the first author to propose a possible diagnosis between what is herein described as Salminus franciscanus (his $S$. cuvieri) and the sympatric $S$. hilarii. Lütken (1875b, 2001), after presenting a thorough morphological comparison between both species, concluded that only scales counts (higher in Salminus franciscanus) and a "difference in teeth size", presumably a reference to the great development of the second dentary tooth in S. franciscanus, distinguished the two species. Lütken $(1875 b, 2001)$ warned that these differential characters should be considered as tentative since he examined only three specimens of Salminus franciscanus (one of which a skin) and a single individual of $S$. hilarii, that he considered a juvenile. That individual measured $8^{1 / 4}$ Danish inches $(=21.6 \mathrm{~cm})$ which would make it rather an adult of this relatively small-sized species of Salminus. Interestingly, Lütken (1875b, 2001) was the first author to notice the discrepancy between the descriptions of Hydrocyon brevidens by Cuvier (1819) and Salminus cuvieri by Valenciennes (in Cuvier \& Valenciennes, 1850). He noted that "Salminus cuvieri Val. cannot be the Hydrocyon brevidens from Cuvier, who, according to the original description, possess more than 100 lateral line scales... being, consequently, more probably identical to the species that inhabits the La Plata River" (Lütken, 2001: 121; our translation). Obviously, Lütken (1875b, 2001) was unaware of the fact that the same specimen was used in the description of both species and that the difference in lateral line counts was due to a mistake by Valenciennes. Steindachner (1880: 80), when describing Salminus affinis, considered this species very similar to $S$. franciscanus (his $S$. cuvieri; hence the epithet "affinis"), from which it was said to be diagnosable only by the presence, in the latter species, of a more robust and developed "canine" tooth ("Hundszahne") (= second dentary tooth) and by the development, in S. franciscanus, of the central caudal-fin rays into a distal projection. As noted under "Diagnosis" and below, both are in fact valid characters to diagnose these species. Steindachner (1880: 82-83) compared Salminus franciscanus with $S$. hilarii, but considered them probably synonymous, believing that specimens of $S$. hilarii were juveniles (thus, ignoring Lütken's observations, who has compared specimens from both species of the same size). Curiously, Steindachner (1880) used Salminus cuvieri for $S$. franciscanus, and, in the same paper, $S$. brevidens for the species from the La Plata basin $(=S$. brasiliensis). Günther (1864) was the first author to employ Salminus brevidens for $S$. franciscanus, a practice that prevailed in the literature from Eigenmann (1916) up to Britski et al. (1984). Finally, Géry \& Lauzanne (1990) noted that Hydrocynus brasiliensis is the older name and consequently has priority over its objective synonyms Hydrocyon brevidens and Salminus cuvieri, and more pertinently that the name should be applied to the Salminus species from the La Plata basin, rather than to one of the species from the rio São Francisco basin.

The more striking diagnostic feature of Salminus franciscanus when compared to its congeners is the great development of the second dentary tooth, which is considerably larger than the remaining dentary teeth. This feature, already reported for the species by previous authors (Lütken, 1875b, 2001; Steindachner, 1880; Géry \& Lauzanne, 1990), is not, however, exclusive to Salminus franciscanus, since $S$. brasiliensis and, to a lesser extent, some examined specimens of $S$. affinis also possess a second dentary tooth distinctly larger than the remaing teeth. However, unlike Salminus franciscanus, which retain a second dentary tooth considerably larger than the re- 
maining teeth throughout its development, in S. brasiliensis the disparity in size between this tooth and the remaining dentary teeth present a ontogenetic change. Individuals larger than $350 \mathrm{~mm}$ SL of the latter species possess this tooth similar in size to the remaining dentary teeth. The great development of the second dentary tooth is the better clue to diagnose Salminus franciscanus from the sympatric S. hilarii, which, inasmuch as possessing a second dentary tooth slightly larger than the remaining teeth in small specimens $(<150 \mathrm{~mm} \mathrm{SL})$, never possess it as developed as $S$. franciscanus. Another interesting feature present in Salminus franciscanus is the great development of the extension of the central caudal-fin extension, throughout of which extends the laterosensory tube. Salminus franciscanus has a well-developed central caudalfin extension, which extends $1 / 3$ or even $1 / 2$ beyond primary margin of fin. Salminus brasiliensis is the only congener to possess an well-developed central caudal-fin extension, which, however, is not as well developed as the one observed in $S$. franciscanus. In Salminus hilarii, the central caudal-fin extension is very short, being apparent only as a small convexity on the distal portion of the caudal fin, while $S$. affinis apparently does not possess any development of the median caudal-fin rays beyond the primary margin of the fin.

\section{Comparative material examined}

Salminus affinis: NMW 78042.2 (1), lectotype; NMW 78042.1 (1), NMW 78042.3 (1), NMW 77149 (2), NMW 56855 (1), paralectotypes. MZUSP 42202 (1); MHNUC-IC-855 (1); BMNH 1947.7.12 (1); MZUSP 35636 (6, 1 cs). Salminus brasiliensis: MNHN A.8555 (1), holotype. MNHN A.8551 (1), holotype of Salminus orbygnianus Valenciennes. MNHN A.8550 (1), holotype of Salminus maxillosus Valenciennes. MZUSP 38873 (4); MZUSP 19378 (2); MZUSP 12430 (1); MZUSP 12907 (1); MZUSP 20500 (1); MZUSP 19439 (1); MZUSP 2069 (1); BMNH 1946.12.23:130-131 (2); MZUSP 19433 (2); MZUSP 4028 (1); MZUSP 19685 (4); MZUSP 19327 (1); MZUSP 19624 (2); MZUSP 19596 (1); MZUSP 19963 (1); MZUSP 19336 (1); MZUSP 19859 (2); MZUSP 21614 (12); MZUSP 20661 (1); MZUSP 14646 (1); MZUSP 16645 (1); MZUSP 16647 (1); MZUSP 14648 (1); MZUSP 14649 (1); MZUSP 14662 (1); MZUSP 14663 (1); MZUSP 21615 (1); MZUSP 21614 (1); MZUSP 21081 (13); MZUSP 27183 (2); MZUSP 36355 (1); MZUSP 4381 (1); MZUSP 20437 (1); MZUSP 36725 (1); MZUSP 35868 (1); MZUSP 81125 (1); MZUSP 88600 (1); MZUSP 14846 (1); MCP 15826 (1); MZUSP 85578 (7, $3 \mathrm{cs})$; MZUSP 85580 (13, $3 \mathrm{cs})$; BMNH 1935.6.4.156 (1); MCP 21141 (1); MCP 21608 (2); MCP 21143 (1); MCP 21737 (1); MCP 31824 (1); MCP 34448 (1); MCP 28694 (1); MCP 26679 (1); MCP 21604 (1); MCP 22019 (1); MCP 22020 (1); MCP 22021 (1); MCP 22022 (1); MCP 22023 (1); MCP 21140 (3); MCP 21142 (3) MCP 32528 (1); MCP 14532 (1); MCP 20687 (1); MCP 27001 (3); MCP 27129 (6); MCP 29059 (1); MCP 27859 (1); MCP 27860 (1); MCP 27129 (11); MCP 28073 (1); BMNH 1878.10.29.3 (1); BMNH 1881.7.2.18 (1); BMNH 1878.5.16.51-52 (2); BMNH 1890.5.15.10 (1); MNHN 1989-1436 (1); NMW 56878 (2); BMNH 1895.5.17.239-240 (2); BMNH 1872.6.8.25-26 (2). Salminus hilarii: MNHN A.8658 (1), lectotype. MNHN A.8557 (1), paralectotype. MZUSP 47772 (1); MCP 34580 (1); MZUSP 73367 (1); MNRJ 19773 (1); MNRJ 17613 (2); MCP 28311 (1); MZUSP 84497 (3); MZUSP 38874 (9); MZUSP 20471 (6); MZUSP 20468 (2); MZUSP 45271 (3); MNRJ 18173 (1); MNRJ 18165 (1); MNRJ 17079 (1); MZUSP 20263 (2); MZUSP 47936 (1); MZUSP 1970 (1);
MZUSP 20475 (3); MZUSP 2056 (1); MZUSP 19516 (1); MZUSP 19650 (2); MZUSP 19515 (1); MCP 14436 (1); MZUSP 53461 (1); MZUSP 45263 (7); MZUSP 45267 (1); MZUSP 45276 (2); MZUSP 19461 (2); MZUSP 35740 (4); MZUSP 45266 (3); MZUSP 1528 (3); MZUSP 45272 (4); MZUSP 2067 (1); MZUSP 45264 (2); MZUSP 45261 (2); MZUSP 45262 (2); MZUSP 45265 (1); MZUSP 19340 (1); MZUSP 19469 (2); MZUSP 19462 (3); MZUSP 80934 (3); MZUSP 19479 (1); MZUSP 19482 (2); MZUSP 19497 (1); MZUSP 19480 (3); MZUSP 19390 (1); MZUSP 19488 (1); MZUSP 19476 (1); MZUSP 3044 (12); MZUSP 83372 (1); MZUSP 40113 (8, 2 cs); MZUSP 19510 (4); MZUSP 19962 (2); MZUSP 3049 (1); MZUSP 45273 (4); MZUSP 45278 (1); MZUSP 45277 (2); MZUSP 45275 (3); MZUSP 45279 (1); MZUSP 19648 (1); MZUSP 20264 (1); MZUSP 19492 (1); MZUSP 83691 (2); MZUSP 3362 (1); MZUSP 19673 (2); MZUSP 1536 (4); MZUSP 2087 (2); MZUSP 1546 (4); MZUSP 2038 (1); MZUSP 2001 (1); MZUSP 1791 (1); MZUSP 1656 (6); MZUSP 2035 (1); MZUSP 2011 (1); MZUSP 1967 (3); MZUSP 86921 (3); MZUSP 45274 (7); MZUSP 21615 (1); MZUSP 374 (1); MZUSP 19852 (1); MZUSP 82102 (1); MZUSP 21080 (1); MZUSP 19927 (1); MZUSP 45258 (4); MZUSP 45257 (5); MZUSP 45260 (4); MZUSP 45259 (2); MZUSP 45256 (6); MCP 14055 (2); MCP 14122 (5); MNRJ 24199 (4); MZUSP 73749 (1); MZUSP 73834 (1); MZUSP 47311 (3); MZUSP 47467 (1); MCP 16711 (2); MZUSP 45280 (2); MCP 34641 (1); MNRJ 18055 (3); MNRJ 18153 (2); MNRJ 18134 (3); MNRJ 18156 (1); MNRJ 18159 (1); MNRJ 18132 (3); MNRJ 18116 (1); MNRJ 18135 (1); MNRJ 18155 (1); MNRJ 18262 (1); MNRJ 18263 (1); MNRJ 17613 (2); MCP 18055 (3); NMW 5686 (2).

\section{Acknowledgements}

We are grateful to the following individuals who have assisted the senior author during research visits associated with this project: Paulo Buckup, Marcelo R. Britto, Arion Aranda, Felipe Melo, and Miriam Ghazzi (MNRJ); Roberto Reis, Luiz Malabarba, Carlos Lucena, Vinicius Bertaco, Édson Pereira, and Cíntia Kaefer (MCP); Jansen Zuanon, Lúcia Rapp Py-Daniel, Éfrem Ferreira, Geraldo M. Santos, and Leandro Sousa (INPA); Robson T.C. Ramos and Ricardo S. Rosa (UFPB); Helmut Wellendorf, Ernst Mikschi, Christa Prenner, and Mathias Reithofer (NMW); Patrice Pruvost, Guy Duhámel, Laurent Nandrin, and Javier Gregorio (MNHN); Ralf Britz, Lukas Rüber, and James Maclaine (BMNH). Pablo Lehmann (MHNUC) has lent a valuable specimen of the now rare S. affinis. Carlos B.M. Alves (Bio-Ambiental Consultoria, Belo Horizonte) provided color pictures of living $S$. franciscanus, including the one used here as Fig. 3, and was instrumental in claryfing several minor problems related to localities. Maraísa Ribeiro also provided photographs of a living specimen of $S$. franciscanus. Eduardo G. Baena radiographed specimens and prepared Fig. 4. Alberto Akama collected and prepared the skeletonized specimen used in this study. Yoshimi Sato (CODEVASF, Estação de Hidrobiologia e Piscicultura de Três Marias, Três Marias) provided various information about the species. Two anonymous reviewers greatly contributed for the improvement of the present paper. This paper is a portion of a Ph.D. Thesis (Lima, 2006), and we are grateful to FAPESP (Grant \# 01/14449-2) for the financial support to the senior author. This paper is dedicated to the memory of Jacques Géry (1917-2007). 


\section{Literature Cited}

Alves, C. B. M. \& P. S. Pompeu. 2001. A fauna de peixes da bacia do rio das Velhas no final do século XX. Pp. 165-187. In: Alves, C.B.M. \& P.S. Pompeu (orgs.), Peixes do rio das Velhas: passado e presente. Belo Horizonte, SEGRAC, 194p.

Bemis, W. E., E. J. Hilton, B. Brown, R. Arrindell, A. M. Richmond, C. D. Little, L. Grande, P. L. Forey \& G. J. Nelson. 2004. Methods for preparing dry, partially articulated skeletons of Osteichthyans, with notes on making Ridewood dissections of the cranial skeleton. Copeia, 2004(3): 603-609.

Böhlke, J. E., S. H. Weitzman \& N. A. Menezes. 1978. Estado atual da sistemática dos peixes de água doce da América do Sul. Acta Amazônica, 8(4): 657-677.

Britski, H. A., Y. Sato \& A. B. S. Rosa. 1984. Manual de identificação de peixes da região de Três Marias. Brasília, Câmara dos Deputados/CODEVASF, 115p.

Calcagnotto, D., S. A. Schaefer \& R. DeSalle. 2005. Relationships among characiform fishes inferred from analysis of nuclear and mitochondrial gene sequences. Molecular Phylogenetics and Evolution, 36: 135-153.

Cuvier, M. G. 1819. Sur les poissons du sous-genre Hydrocyn, sur deux nouvelles espèces de Chalceus, sur trois nouvelles espèces de Serrasalmes, et sur l'Argentina glossodonta de Forskahl, qui est 1'Albula gonorhynchus de Bloch. Mémoires du Muséum National d'Histoire Naturelle, 5: 351-371, 2 pls.

Cuvier, M. G. \& A. Valenciennes. 1850. Histoire naturelle des poissons. Tome vingt-deucième. Suite du livre vingt-deuxième. Suíte de la famille des Salmonoides. Table génerale de l'Histoire Naturelle des Poissons (pp. 1-91). Histoire Naturelle des Poissons, 22: i-xx +1 p. $+1-532+1-91$, prs. 634-650.

Eigenmann, C. H. 1916. On the species of Salminus. Annals of the Carnegie Museum, 10 (1-2): 91-92.

Esteves, K. E. \& A. V. Pinto Lôbo. 2001. Feeding pattern of Salminus maxillosus (Pisces, Characidae) at Cachoeira das Emas, MogiGuaçu River (São Paulo State, southeast Brazil). Revista Brasileira de Biologia, 61(2): 267-276.

Fink, W. L. \& S. H. Weitzman. 1974. The so-called Cheirodontin fishes of Central America with descriptions of two new species (Pisces: Characidae). Smithsonian Contributions to Zoology, 172: 1-46.

Géry, J. 1977. Characoids of the world. T.F.H. Publications, Neptune City, 672p.

Géry, J. \& L. Lauzanne. 1990. Les types des espèces du genre Salminus Agassiz, 1829 (Ostariophysi, Characidae) du Muséum National d'Histoire Naturelle de Paris. Cybium, 14(2): 113-124.

Günther, A. 1864. Catalogue of the fishes in the British Museum. Catalogue of the Physostomi, containing the families Siluridae, Characinidae, Haplochitonidae, Sternoptychidae, Scopelidae, Stomiatidae in the collection of the British Museum. Vol. 5. London, Taylor and Francis: i-xxii $+455 \mathrm{p}$.

Lima, F. C. T. 2006. Revisão taxonômica e relações filogenéticas do gênero Salminus (Teleostei: Ostariophysi: Characiformes: Characidae). Unpublished Ph.D. Thesis, Instituto de Biociências, Universidade de São Paulo, São Paulo, 253p.

Lütken, C. F. 1875a. Characinae novae Brasiliae centralis a clarissimo J. Reinhardt in provincia Minas-Gerais circa oppidulum Lagoa Santa in lacu ejusdem nominis, flumine rio das Velhas et rivulis affluentibus collectae, secundum caracteres essentiales breviter descriptae. Oversigt over det Kongelige Danske Videnskabernes Selskabs Forhandlinger, 1974(3): 127-143.

Lütken, C. F. 1875b. Velha-Flodens Fiske. Et Bidrag til Brasiliens Ichthyologi; efter Professor J. Reinhardts Indsamlinger og Optegnelser. Danske Vidensksbernes Selskab Skrifter 12(2): 121$253,+2$ not numbered, + i-xxi, prs. 1-5.

Lütken, C. F. 2001. Peixes do rio das Velhas: uma contribuição para a ictiologia do Brasil, de acordo com as coleções e descrições do Professor Johannes Theodor Reinhardt. Pp. 23-164. In: Alves, C. B. M. \& P. S. Pompeu (orgs.), Peixes do rio das Velhas: passado e presente. SEGRAC, Belo Horizonte, 194p.

Malabarba, L. R. \& S. H. Weitzman. 2003. Description of a new genus with six new species from southern Brazil, Uruguay and Argentina, with a discussion of a putative characid clade (Teleostei: Characiformes: Characidae). Comunicações do Museu de Ciências e Tecnologia da PUCRS, série Zoologia, 16(1): 67-151.

Menezes, N. A. \& S. H. Weitzman. 1990. Two new species of Mimagoniates (Teleostei: Characidae: Glandulocaudinae), their phylogeny and biogeography and a key to the glandulocaudin fishes of Brazil and Paraguay. Proceedings of the Biological Society of Washington, 103: 380-426.

Moraes Filho, M. B. \& O. Schubart. 1955. Contribuição ao estudo do dourado (Salminus maxillosus Val.) do rio Mogi Guassu (Pisces, Characidae). Ministério da Agricultura, Divisão de Caça e Pesca, São Paulo, 130p.

Müller, J. \& F. H. Troschel. 1844. Synopsis generum et specierum familiae Characinorum. Archiv für Naturgeschichte, 10(1): 81-99.

Müller, J. \& F. H. Troschel. 1845. Horae ichthyologicae. Beschreinbung und Abbildung neuer Fische. Erstes und Zweites Heft. Die familien der Characinen. Berlin: Verlag von Veit \& Comp., 40p.

Nakatani, K., A. A. Agostinho, G. Baumgartner, A. Bialetzki, P. V. Sanches, M. C. Makrakris \& C. S. Pavanelli. 2001. Ovos e larvas de peixes de água doce. Desenvolvimento e manual de identificação. Universidade Estadual de Maringá/Eletrobrás/ Nupelia, 378p.

Ortí, G. \& A. Meyer. 1997. The radiation of characiform fishes and the limits of resolution of mitochondrial DNA sequences. Systematic Biology, 46(1): 75-100.

Petrere Jr., M. 1989. River fisheries in Brazil: a review. Regulated Rivers: Research and Management, 4: 1-16.

Pompeu, P. S. \& H. P. Godinho. 2006. Effects of extended absence of flooding on the fish assemblages of three floodplain lagoons in the middle São Francisco River, Brazil. Neotropical Ichthyology, 4(4): 427-433.

Roberts, T. 1969. Osteology and relationships of the characoid fishes, particularly the genera Hepsetus, Salminus, Hoplias, Ctenolucius, and Acestrorhynchus. Proceedings of the California Academy of Sciences, 36(15): 391-500.

Rodríguez-Olarte, D. \& D. C. Taphorn. 2006. Abundance, feeding and reproduction of Salminus sp. (Pisces: Characidae) from mountain streams of the Andean piedmont in Venezuela. Neotropical Ichthyology, 4(1): 73-79.

Santos, J. E. \& H. P. Godinho. 2002. Ontogenetic events and swimming behavior of larvae of the characid fish Salminus brasiliensis (Cuvier) (Characiformes, Characidae) under laboratory conditions. Revista Brasileira de Zoologia, 19(1): 163-171.

Sato, Y. \& H. P. Godinho. 1999. Peixes da bacia do rio São Francisco. Pp. 401-413. In: R. H. Lowe-McConnel. (Ed.). Estudos ecológicos de comunidades de peixes tropicais. Edusp, São Paulo, 534p.

Sato, Y. \& H. P. Godinho. 2003. Migratory fishes of the São Francisco River. Pp. 195-232. In: J. Carosfeld, B. Harvey, C. Ross \& A. Baer (Eds.). Migratory fishes of South America: biology, fisheries and conservation status. World Fisheries Trust/The World Bank/ International Development Research Centre, Ottawa, 372 pp.

Steindachner, F. 1880. Zür Fisch-Fauna des Cauca und der Flüsse bei Guayaquil. Denkschriften der MathematischNaturwissenschaftlichen Classe der Akademie der Wissenchaften, Wien, 42: 55-104, 9 pls.

Sverlij, S. B. \& A. Espinach Ros. 1986. El dorado, Salminus maxillosus (Pisces, Characiformes) en el Río de La Plata y Río Uruguay inferior. Revista de Investigación y Desarollo Pesquero, 6: 57-75.

Taylor, W. R. \& G. C. Van Dyke. 1985. Revised procedures for staining and clearing small fishes and other vertebrates for bone and cartilage study. Cybium, 9(2): 107-119.

Vari, R. P. \& L. R. Malabarba. 1998. Neotropical ichthyology: an overview. Pp. 1-11. In: L. R. Malabarba, Reis, R. E., R. P. Vari, Z. M. S. Lucena \& C. A. S. Lucena (eds.), Phylogeny and Classification of Neotropical Fishes. Porto Alegre, Edipucrs, 603p.

Submitted May 2006 Accepted April 2007 